\title{
Comercio y tributo en Apolobamba. La crítica ilustrada a las órdenes misioneras
}

\section{Daniel J. Santamaría}

CONICET-Argentina

\begin{abstract}
Este artículo examina las críticas ilustradas al orden misional en las selvas de Apolobamba, una fracción de piedemonte al norte de La Paz (Bolivia) en el siglo XVIII. Esas críticas cuestionan los aspectos formales y las fuentes de sostenimiento económico de la zona, proponiendo una progresiva libertad de los indígenas reducidos con el fin de aumentar las relaciones de mercado entre Apolobamba y las ciudades coloniales y en paralelo, el ingreso fiscal tributario.

Palabras Clave: Bolivia, Apolobamba, Comercio colonial, Tributo real, Ilustración.
\end{abstract}

This article studies the enlightened criticisms to missionary orders in Apolobamba forests, a piedmont zone in northern La Paz district (Bolivia) during the 18th century. These criticisms put on discussion the formal aspects and the sources of regional economic support, proposing a progressive liberty of indians reduced in missions, with the goal of increasing the market relations between Apolobamba and colonial towns, and simultaneously, the State taxes.

KeYwords: Bolivia, Apolobamba, Colonial trade, Royal taxes, Enlightenment.

En la segunda mitad del siglo XVIII, muchos funcionarios ilustrados comienzan a criticar algunos aspectos de las economías misionales en Hispanoamérica: las de franciscanos y agustinos no forman excepción. Las dádivas, el monopolio comercial, el manejo caprichoso del dinero, la exención de tributos; el subsidio estatal figura, como corresponde, entre los principales. Uno de los argumentos más comunes durante la primera mitad de ese siglo entre los cada vez más numerosos enemigos de franciscanos y agustinos es la riqueza natural de las misiones del piedemonte de Apolobamba, las verdes vertientes de los Andes al norte de La Paz, en Bolivia. La variedad productiva, difundida por soldados y mercaderes, niega la imagen de pobreza que los regulares suelen esgrimir para perpetuar la ayuda gubernamental. Otro argumento es la popular idea de que hay en Apolobamba ricos yacimientos de oro y plata, cuya explotación haría inne- 
cesarios los subsidios. Otro, que pretextando la permanente falta de subsidios estatales, los frailes aprovechan para explotar sin moderación el trabajo de los indios. Movidos por estas nuevas ideas, las autoridades piden desde mediados del XVIII y casi obsesivamente, informes de toda clase. Esta reiteración, que promueve, por fortuna para nosotros, voluminosos expedientes documentales, se apoya en algunas sospechas básicas. ¿Cuántos son, realmente, los pueblos reducidos en Apolobamba? ¿cuánta riqueza producen y cuánto retienen los misioneros? ¿cuál es el número exacto de indios reducidos? Debemos preguntarnos si es probable que este sistema misional, a principios de siglo apoyado con tanto entusiasmo, resulte, de pronto, tan desconocido y problemático para las autoridades de mediados del XVIII? Los testimonios son abundantes y confiables porque en general emanan de expertos. Al expresar la presunta confusión existente sobre el número de misiones y misioneros, las autoridades civiles y eclesiásticas denuncian implícitamente el caos que atribuyen a la creciente autonomía con que los provinciales franciscanos designan a sus operarios, planifican sus expediciones evangelizadoras y usan el dinero y los recursos materiales que reciben. Este supuesto "desconocimiento" de la labor de los regulares se encuadra dentro del cuestionamiento sistemático que los ilustrados hacen de su autonomía, de la que nacen la explotación y el monopolio. Revisar los fondos, achicar los presupuestos y cuestionar la atención de las misiones son actitudes políticas que marcan, de modo que veremos irreversible, el descontento del estado borbónico por las autonomías misionales. En febrero de 1766 el obispo de La Paz recibe un informe del general Diego de Alvarado y en octubre, otro de Diego de Oblitas. Alvarado, justicia mayor de Larecaja y notorio enemigo de los franciscanos, le entrega al obispo Campos una secreta que incluye la lista de frailes actuantes en Apolobamba, incluyendo el pueblo criollo de Sagunt.

"Los religiosos que poseen el nombre de misioneros y se hallan en aquellos pueblos se destinan más al cultivo de intereses propios que al fruto de su ministerio, como lo testifican las gruesas siembras de arroz, cacao para el beneficio del chocolate, algodones y otros frutos que producen aquellas tierras con cuyo declarado comercio, se invierte el principal fin de su destino, teniendo a los infelices indios esclavizados siempre en este ejercicio". ${ }^{1}$

1 Archivo de la Catedral de La Plata (ACLP), legajo 25. Campos, Gregorio Francisco de, Autos que en cumplimiento de Real Cédula de Su Majestad, expedida a pedimento del Padre Procurador de esta Provincia de San Antonio del Orden de San Francisco, se formen para indagar si es conveniente se le devuelva a dicha religión el curato de la doctrina de Charasani que antes poseía por los motivos que expresa para que subsistan las Misiones de Apolobamba, 1765. 
Varios testigos confirman la denuncia de Alvarado: según un vecino de Sorata, Miguel de Contreras, los franciscanos de Atén hacen trabajar a los indios en los cultivos de arroz, cacao y algodón, en buscar cera y en el tejido del algodón, donde ocupan "mucha gente". El cacique de Charasani, Pablo Serena (descendiente del cacique anti-franciscano Martín), protesta que durante la administración seráfica, los indios sufrían

\begin{abstract}
"pensiones de mucho peso, como las que siempre que les ofrecía regresar a lo interior de su provincia, eran precisados al servicio personal en su compañía y de expresos hasta la ciudad del Cuzco, Arequipa, Oruro y Cochabamba cuya distancia ser de cien leguas, la menor; y que esta pensión la cumplían sin disputa estos miserables por reconocer la obligación".
\end{abstract}

Esta ausencia tan dilatada de los indios arruinaba, según estos críticos, sus "casas y haciendas". Los reproches no sólo apuntan al tema de la explotación del indio, sino al espíritu comercial que la anima y que los testigos señalan claramente: Gaspar Cáceres dice que cuando fray Diego Aramburu gobernaba Charasani venían algunos misioneros a ese pueblo pero no sabe si a restablecer su salud o a "negocios bien distintos". Otro testigo, Diego Alvarez, que conoce bien la riqueza de Apolobamba, no está tan seguro de que los frailes vinieran a Charasani sólo por sus baños termales sino "para otras inteligencias y comercios". Los ilustrados denuncian que las opciones laborales elegidas por los frailes no son las únicas posibles ni fueron desarrolladas sólo por espíritu misional. Es evidente que las órdenes se quedan con una parte importante del producto de cada misión y que pueden cambiarlo por moneda en los mercados externos. La continua solicitud de fondos, los abandonos de misiones por falta de subsistencias y los reparos al cobro de tributos generan una convincente imagen de pobreza, que los ilustrados están bien dispuestos a cuestionar.

El nuevo maestre de campo de las misiones, José de Santa Cruz y Villavicencio, denuncia que cada doctrinero exige de sus neófitos media arroba de cacao para su sustento personal - dato que confirman Crespo y Llanos - quedando el resto como stock de la misión, administrado por el cura que lo vende en su exclusivo provecho. Los aborígenes no hacen, en realidad, más que transportar los bienes por los ríos, pero si quieren venderlos por su cuenta, deben hacerlo furtivamente asumiendo que la trasgresión del monopolio comercial franciscano se sanciona con severidad. Y esto ocurre con cualquier clase de producto, incluso con ceras y resinas, de menor aceptación en el mercado. Los frailes les conceden a los nativos sólo 
un día libre por semana para que lo aprovechen en sus propias labores. Gozan de doce semanas de licencia por año para cultivar sus huertos, pero el resto del tiempo lo ocupan en la producción controlada por la orden, que no se remuneran de modo alguno. Manzaneda ofrece un panorama similar pero con diferencias de detalle: no en todas las misiones se les paga a los indios, dejando entender que sí lo hacen en algunas. ${ }^{2}$

El trabajo indígena en cocales, chacras y cacaguales administrados por los frailes dura tres semanas por mes (es decir 113 de licencia y no 84 como cree Santa Cruz). Durante la cuarta semana de cada mes los indios se concentran en sus propias labores. Manzaneda deduce que por esto viven "aborreciendo tanto trabajo, estrechura y subordinación". Fuera como fuere el régimen de trabajo, los informes gubernamentales coinciden en describir un sistema que asigna a las sumarias economías domésticas de los grupos reducidos los costos de recomposición de la fuerza de trabajo. Que este sistema logra que los frailes reúnan un excedente apreciable (menor, sin embargo, a lo que creen los oficiales reales, impresionados por la riqueza de otras misiones) lo confirma Santa Cruz: "no se sabe en qué invierten las cantidades tan crecidas de coca que mandan a la Procuración".

\section{El informe del obispo Juan Pablo de Olmedo}

Luego de cumplir una de sus periódicas visitas diocesanas hacia 1752, el obispo de Santa Cruz de la Sierra, Juan Pablo de Olmedo, lamenta comunicar que él mismo ha podido comprobar la decadencia de las misiones franciscanas en Apolobamba. Entre las medidas que aconseja para solucionar lo que considera un "problema mayor", propone anexarlas a las reducciones jesuitas de Mojos y Chiquitos. Además, recomienda encargar la doctrina de Pocona a un seglar y quitársela al guardián franciscano, que por esa función percibe 1.250 pesos anuales de sínodo, dando sólo cien al cura doctrinero. Para justificar esta solicitud, Olmedo señala que si el doctrinero recibe tan poco dinero, se produce "la minoración de feligreses". Las propuestas de Olmedo sorprenden por su radicalismo. Es posible que tuviera en cuenta el mejor desempeño de los jesuitas en la administración misional o que representara los intereses de los mercaderes de su ciudad. La

2 Archivo General de la Nación Argentina (AGN)-Interior, 28:3. Manzaneda, Jacinto R. (1785) Informe al gobernador intendente de La Paz, 3 de mayo de 1785. 
alianza de las autoridades cruceñas con las reducciones jesuitas en Chiquitos es probable; pero en este caso habría que suponer que los mercaderes tienen no sólo aspiraciones sobre Mojos (como siempre) sino sobre las más alejadas misiones de Apolobamba. Las ferias indígenas del Beni y el rol estratégico de los jesuitas en Reyes explican este repentino interés cruceño por abrir el comercio en esa dirección, lo que incluye (de más está decirlo) los mercados de La Paz y el Cusco.

De todos modos, y en medio de la hostilidad desatada entre el gobierno borbónico y las órdenes regulares, la denuncia de Olmedo parece la señal convenida para que las autoridades políticas y eclesiásticas desencadenen una larga campaña contra los regulares. En este caso, Olmedo utiliza una propuesta que seguramente enfrentará a jesuitas y franciscanos. En carta al rey, fray Pedro Domínguez señala que "en otros tiempos" los jesuitas no pudieron conseguir paso franco por las misiones de Apolobamba, de lo que se siguió un pleito ante el monarca. Pero los propios jesuitas parecen ahora ignorar la solicitud de Olmedo, cosa que los franciscanos obviamente no pueden hacer. Conocida la propuesta, Madrid pide informes, en septiembre de 1754, a la Audiencia de Charcas y al virrey marqués de Valdelirios. En noviembre de 1755, éste responde que como las misiones están alejadas no se sabe de ellas más que lo que dicen los impresos jesuitas, coincidentes con lo que sobre el progreso de sus misiones dijo el obispo cruceño. Mientras que en las misiones franciscanas "sobresalían a la vista del prelado en aquellos desiertos, la pobreza e ignorancia". Aún en las ciudades se nota, a juicio del virrey, la diferencia entre las órdenes mendicantes y la limpieza política y economía de la Compañía de Jesús, y así es que en éstas florecía "toda aquella racionalidad y cultura que lograban los que con más anticipado tiempo se habían fundado en la América". Aunque avala el pedido episcopal, Valdelirios aconseja la prudencia sabiendo que los franciscanos ya han sido beneficiados con dos permisos: uno a fray José de San Antonio, comisario de las misiones del Cerro de la Sal, para que 60 frailes reduzcan a los neófitos de Apolobamba que desertaron "incitados del indio rebelde" que habita en las inmediaciones de Tarma (referencia al movimiento revolucionario de José Santos Atahualpa de 1742); y otro a fray Isidoro de Cala para llevar otros doce a fomentar las misiones de las vertientes del Cusco.

Valdelirios se pregunta ¿cómo tomar la orden la propuesta episcopal? No sabe si el obispo ha amonestado al provincial franciscano. Cree que resulta prudente instruir de todo al obispo de Santa Cruz para que agote 
todas las instancias antes de poner en manos de los jesuitas dichas misiones. Agrega que si se encontrasen "algunos [pueblos de indios] que por la menos distancia a las poblaciones del Perú estuviesen mejor instruidos en la fe o con más cultura en lo racional" debería encomendarlas a curas seglares. Antes de responder al rey, la Audiencia pide informes al gobernador de Santa Cruz y al de Mojos, al deán y cabildo en sede vacante del obispado de Santa Cruz (por fallecimiento de Olmedo), al padre superior de las misiones de Mojos y al provincial de San Francisco. Uno de los informes solicitados por el obispado de La Paz corresponde al cura vicario de Camata, licenciado Buenaventura José Rodríguez, fechado 18 de marzo de 1756.

La Audiencia de Charcas asume la propuesta de Olmedo casi con indiferencia. Responde en febrero de 1758 que ya hay cura seglar en Pocona y que no considera necesaria la agregación solicitada, porque si bien en años pasados decayeron algo las misiones franciscanas, ya estaban mejor. En una repentina concesión a los intereses del Cusco, expresa que en todo caso sería conveniente abrir un camino Cusco-Apolobamba para que por él se transite hasta Mojos y Chiquitos. Esta concesión tiene que ver con los intereses mercantiles de las tierras altas con los cuales la Audiencia se compromete progresivamente: por ello también propone que se permita que los indios de Apolobamba comercien directamente con los españoles, aboliendo el viejo monopolio franciscano. También solicita el empadronamiento de los indios y que se les imponga "vasallaje al rey", un eufemismo que significa imposición de tributos. Finalmente, pide que se instale un gobernador político en lo temporal dejando a los franciscanos sólo la tarea espiritual. De esta manera, la Audiencia de Charcas fija su oposición ideológica contra el envejecido corporativismo que representan los misioneros regulares y, simultáneamente, su oposición comercial contra Santa Cruz con la que coincide, naturalmente, en la ideología del nuevo liberalismo "aperturista" recomendado por los ilustrados. Por último, los oidores se encargan de advertir que el cabildo eclesiástico de Santa Cruz no ha elaborado el informe que se le solicitara, pero que de todos modos "no se contempla necesario". A la vista de los informes del virrey y del tribunal de Charcas, el fiscal de la Audiencia no encuentra razón para anexar Apolobamba a las misiones jesuitas ${ }^{3}$ pero sí decide participar en la cuestión fundamental que subyace en todo el proceso, recomendando que

3 Archivo de la Cancillería de la República de Bolivia (ACRB), legajo 6. 


\begin{abstract}
"se permita a los españoles que quisieren entrar a aquellos parajes para sus comercios que lo puedan ejecutar en libertad para contratar con los indios, cuyo trato y comunicación es muy conveniente, y de ello resultar el más pronto y continuo dispendio de los frutos que producen aquellos países y se inclinan con más anhelo al cultivo de aquellos amenos y fértiles campos". ${ }^{4}$
\end{abstract}

\title{
Las críticas ilustradas a la economía misionera
}

Los funcionarios liberales desean esclarecer exactamente dos cuestiones: si los territorios misionados pueden incorporarse realmente al mercado colonial y si una producción sostenida les permitiría a los productores nativos pagar tributo a la Corona. El primer tema los lleva a precisar montos, costos, gastos de producción y transporte. La segunda los lleva a explayarse en largas especulaciones filosóficas (casi antropológicas) sobre las bondades del trabajo libre y el tributo. Las autoridades ilustradas consideran nocivo e inútil el tradicional sistema franciscano de regalar a los nativos cosas de poco valor, método que sólo basta para asegurar la estabilidad de la misión con un mantenimiento mínimo. En efecto, los frailes importan a las misiones chalonas, quesos y terneros, a veces sólo para negociarlos con mercaderes cruceños y alguna coca para los nativos. Reparten entre sus acólitos, además de los abalorios condenados por los liberales, cotones de bayeta, carne o sal. Consciente de esta problemática, un informe de la Real Contaduría de $1793,{ }^{5}$ apela a un examen etnológico:

\begin{abstract}
"en esta materia de reducciones de bárbaros, es menester confederar el celo con la prudencia. Está ya averiguado y conocido con una consumada experiencia que las erogaciones gratuitas de bujerías, abalorios, herramientas, etcétera, producen en el genio desconfiado de los bárbaros un perjudicial recelo cuando las reciben satisfactoriamente, mucha emulación, avaricia o codicia, cuando se las escasea. La máxima probada ya en el Canadá, Batavia, a la otra banda del Marañón, etcétera, es introducir estas liberalidades con el aparente aprecio de la permutación y el cambio, aunque lo que se les quita sea tan despreciable que a vuelta de su rostro, o en su retiro, se haya de botar y disipar como inútil. En una palabra, la introducción del comercio y el anhelo a su propio trabajo, es en lo sucesivo lo que ha de afianzar la subsistencia de la reducción".
\end{abstract}

Es cierto que los intercambios gratuitos con los nativos han tenido hasta entonces un fin estratégico. El sistema misional nunca analizó concretamente el potencial productivo de sus territorios y sus posibles lazos

4 ACRB. Auto de la Real Audiencia de Charcas, 21 de mayo de 1757

5 AGN. Informe de la Real Contaduría de Buenos Aires, 1793. 
comerciales con el mundo andino. El intercambio gratuito sólo actuó como pretexto para pulir un contacto exclusivamente social, capaz de garantizar la seguridad jurisdiccional (y de alguna manera su aislamiento) y por ello, cierta estabilidad política en la región. Pero el leitmotiv es la generación y acumulación de excedentes por parte de los franciscanos, y el elemento fundamental de este proceso de acumulación es el trabajo gratuito de los indios. Con esto quieren terminar los ilustrados.

\section{Los bienes de exportación}

¿Cuáles son los bienes, producidos masivamente, que le permitirían a Apolobamba incorporarse al mercado y a sus productores pagar el tributo? Se piensa, básicamente, en cuatro productos de buena aceptación en los mercados urbanos coloniales, pero de distinta dimensión: los tejidos de algodón y el tabaco, en un plano menor, y el cacao y el chocolate elaborado, sobre los cuales los funcionarios tienen mayores esperanzas. Para Esprellia, la riqueza de Apolobamba reside en su exportación de cacao, arroz, maní, tamarindos, palillos y cera a Arequipa, Cusco y La Paz. La coca es un buen giro porque los nativos no la usan; lo mismo ocurre con el arroz, que apenas integra la dieta aborigen. Todos los bienes destinados a la exportación se remiten a la procuración franciscana de Pelechuco, que los traslada a las poblaciones españolas. Muchos sostienen que, incluso, Apolobamba puede producir mucho de lo que compra en el exterior: por ejemplo, dispone de caña para fabricar azúcar y de parras para elaborar vino. El algodón silvestre, y sobre todo el cultivado con semillas importadas, es de calidad superior, pero sólo sirve normalmente como materia prima para la labor textil de las unidades domésticas misionales: sobrecamas, paños de manos, camisetas para los varones y taramas para las mujeres, una especie de saya que las viste desde los hombros hasta los talones. Parte de esta producción se trueca en los pueblos de indios por alimentos o "ropa de la tierra". El resto, según la vieja costumbre franciscana, se remite a la procuración de Pelechuco, confiándola al procurador o a sus apoderados. Pero no hay cifras sobre el volumen negociado. En Uchupiamonas, Tumupasa e Isiamas, el promotor fiscal Pedro Crespo y el defensor de la Real Hacienda Miguel de Llanos ${ }^{6}$ mencionan una artesanía tradicional de tejidos de algodón, además de los

6 AGN-Interior, 28:3. Crespo, Pedro y Miguel de Llanos, Carta al gobernador Sebastián de Segurola, 11 de marzo de 1786. 
plumeros y plumajes, pieles de tigre y artículos de madera y paja. Creen firmemente que el algodón puede dejarles a los indios reducidos un buen rédito. Con la vista puesta en la tasa tributaria, explican que aun cuando el algodón falte, los nativos podrán pagar ocho mazos de tabaco de buena calidad, de dos libras cada uno. La producción constante de algodón o tabaco deja habitualmente excedentes anuales para el intercambio. Santa Cruz considera que el comercio libre de estos productos les reportaría bastante utilidad porque no hay otra opción que trasladar las cargas de un pueblo al otro en hombros, pagando los interesados.

\section{El posible comercio de cacao}

Los nativos de Isiamas comercian a mediados del XVIII con los jesuitas de Reyes, sobre la otra margen del Beni, pero también navegan aguas abajo hasta el Guaporé para hacer sus ferias, en viajes que duran hasta treinta días. De estas misiones salen los doscientos 50 quintales del cacao que Crespo incorpora a su estadística de $1786^{7}$ y del que Haenke dice que "excede en bondad muchas veces al de Guayaquil". ${ }^{8}$ Pero no hay cultivos organizados de cacao y el poco que recogen lo cambian por diversos productos con los mercaderes de Santa Cruz. Crespo y Llanos calculan en 1785 que los indios recogen de ocho a diez libras anuales de cacao y que se les podrá cobrar tributo en cacao en grano antes que subsidiarlos para que lo elaboren en bollos. Sin embargo, dudan de la habilidad nativa para elaborar un alimento que suele perderse fácilmente en los largos caminos de montaña. Para peor, no recogen cacao silvestre todos los años porque las bandadas de monos los devoran y otras plagas los echan a perder. Pese a ello, consideran que un cultivo regular garantizaría una provisión eficiente y segura. Que en Uchupiamonas, Tumupasa e Isiamas los indios abandonen los cacaguales sólo porque no tienen a quién venderle el cacao, señala que éste no forma parte substancial de la dieta aborigen como la mandioca o el plátano, que los nativos comparten con los misioneros. Aunque en algunos años pierden el cacao silvestre, los toromonas pueden cultivarlo en sus propios cacaguales y esperar los tres años que la planta tarda en fructificar. La esporádica producción de cacao en Carmen de Toromonas sólo

7 AGN-Interior, 28:3. Crespo y Llanos, Carta al gobernador...

8 Haenke, Tadeo, Memoria sobre los ríos navegables que fluyen al Marañón, en Tadeo Haenke, Su Obra en los Andes y la Selva Boliviana, La Paz-Cochabamba, 1974, página 133. 
podría asegurarse con algún mínimo criterio de conservación. Además, los mercaderes cruceños se llevan el cacao de las aldeas del norte para cambiarlo por otros bienes. El informe añade que estos comerciantes son "misioneros de jesuitas", lo que, lapsus calami mediante (la Compañía ha sido expulsada en 1767), puede significar que son viejos proveedores de los jesuitas, antiguos neófitos ahora afincados en Santa Cruz o residentes en los circuitos comerciales que la unen con las misiones de Apolobamba. Estas son muy activas con los transportes de mercaderes españoles que pagan bien a los curas que organizan y dirigen a los balseros. Como corresponde a un burócrata ilustrado, Santa Cruz y Villavicencio protesta que los curas se aprovechan de todo sin darle a los cargadores ni siquiera los víveres del viaje.

A manera de resumen, veamos las cifras que manejan para fundamentar sus proyectos. Cotejemos los precios mencionados en el informe de Manzaneda de mayo de $1784^{\circ}$ y en el de Santa Cruz y Villavicencio de febrero de $1785 .{ }^{10}$ Ambos proporcionan cifras análogas para la producción pero muy distintas para los precios. Las medidas usadas entonces eran el quintal (cuatro arrobas), y la arroba (25 libras).

\section{PRODUCCIÓN ANUAL Y PRECIOS EN APOLOBAMBA}

\begin{tabular}{llccc} 
Producto & Unidad & $\begin{array}{c}\text { Producción } \\
\text { anual }\end{array}$ & $\begin{array}{c}\text { Precio en reales } \\
\text { en 1784 }\end{array}$ & $\begin{array}{c}\text { Precio en reales } \\
\text { en 1785 }\end{array}$ \\
\hline Arroz & Quintal & 360 & 64 & $56 / 64$ \\
Cacao & Quintal & 250 & 142 & \\
Coca & Cesto & 1300 & 48 & 80 \\
Chocolate & libra & & 10 & \\
Maní & quintal & 150 & 76 & $72 / 80$
\end{tabular}

Sin embargo, el valor exportado desde las misiones muestra otras posibilidades: una producción evaluada en alrededor de 130.000 reales al año no es poca monta para un conjunto de aldeas separadas unas de otras

9 AGN-Interior, 28:3. Manzaneda, Jacinto R. (1785) Informe al gobernador intendente de La Paz, 3 de mayo de 1785 .

10 AGN-Interior, 28:3. Santa Cruz y Villavicencio, José de, Informe sobre las Misiones de Apolobamba, 10 de febrero de 1785 . 
por duros caminos. Precisamente, Santa Cruz destaca esta desintegración geográfica entre las misiones del sur y las del norte de Apolobamba como una cuestión importante. Según Manzaneda, ${ }^{11}$ aunque entre 1771 y 1785 aumentó el comercio entre los españoles y los cinco pueblos del sur, casi no hubo contacto con Carmen de Toromonas, un poco por la distancia de más de trescientos kilómetros — según testimonio de exploradores- - y otro poco porque los franciscanos jamás emplearon a sus neófitos del sur en viajes a ese pueblo. La excepción es Reyes, donde el padre Francisco J. Negrete, protector entusiasta de los toromonas, ha estado enviando a su costa las canoas necesarias. Años después el puerto de Reyes se clausura y ya no habrá balseros en Apolobamba.

\section{La cuestión tributaria}

Al inicio del XVIII, Felipe $\mathrm{V}$ impone tributo a los indios de Apolobamba considerando que ha pasado ya mucho tiempo de evangelización y civilización. En el futuro, todos los funcionarios ilustrados coinciden con esta opinión y derrochan esfuerzos por llevarla a la práctica. El razonamiento es sencillo: con libertad comercial, los indígenas logran un beneficio y por lo tanto pueden pagar tributo. Para la ideología liberal imperante, la posibilidad de pagar imposiciones a la Real Hacienda representa y legitima la libertad política. Sin embargo, y con la mira puesta en reducir el déficit del tesoro, la Audiencia necesita fijar tasas de tributo procediendo, como se recomienda oficialmente, "muy despacio, con gran tiento y suma reflexión" porque se teme que la imposición induzca a los nuevos tributarios a abandonar las misiones. En definitiva, una de las bases sociales requeridas para imponer tributos es reorganizar el trabajo de los indios reducidos.

Cuando la Real Ordenanza de Intendentes de 1782 incluye las misiones de Apolobamba en la nueva intendencia de Caupolicán, las autoridades tienen las manos libres para imponerles tributo a las poblaciones reducidas. Es necesario que el tesoro público se apropie directamente de una parte del excedente generado por el trabajo indígena, hasta entonces sólo útil para enriquecer a las órdenes regulares. En nota remitida al gobernador Segu-

11 AGN-Interior, 28:3. Manzaneda, Informe al gobernador... 
rola, los visitadores Crespo y Llanos redactan una apología del tributo: ${ }^{12}$ suponen

"innata la propensión de todo hombre a buscar, adquirir y gozar bienes sobre bienes, y en tanto grado, que en esto mismo fundan los mejores teólogos para convencer al Altísimo una prueba real que tenemos en nosotros mismos de haber un sumo bien y una suma felicidad a que el hombre puede llegar, capaz de saciar todos sus deseos y capaz de satisfacer todos sus anhelos".

La apelación teológica de los funcionarios no es gratuita: gran parte de las discusiones dogmáticas sobre la usura, el trabajo libre, el uso del capital y el enriquecimiento personal están en la base de la disputa política entre liberales y católicos. Para estos, imbuidas de espíritu escolástico, el ánimo de progreso económico individual, tanto como la riqueza material como opción frente a la espiritual, constituyen poco menos que herejías abominables. Crespo y Llanos concuerdan en que "cuando los naturales de Apolobamba vean que a vuelta del tributo que se les ha impuesto quedan en la libertad y en la certidumbre de trabajar para adquirir y adquirir para gozar con sus mujeres, hijos y familias, estarán más arraigados y con más amor sujetos a los mismos terrenos que cultivan y a las mismas posesiones que adquieren, sin el menor recelo de que puedan fugarse". Trabajar para adquirir y adquirir para gozar. Esta propuesta ilustrada, liberal y fisiocrática, inspirada en la defensa del derecho de propiedad y el trabajo libre, disuelve los últimos residuos del trabajo como "castigo del pecado" y como "muestra de fe y reconciliación". El tributo a la Corona, después de todo, es el reconocimiento jurídico de la libertad del indio y en la práctica, un seguro social contra la explotación de las corporaciones. Los gobernantes creen que una vez dueños virtuales de la tierra que labran, los indígenas no querrán huir. Por lo pronto, a los ojos de los ilustrados, la tasa impuesta a cada unidad doméstica es menor que la parte del valor de su producción por tanto tiempo cedida a la ambición exportadora de los frailes.

¿Cómo es la situación tributaria general de las misiones y qué datos la ilustran? La imposición tributaria se establece oficialmente en 1782 y los revisitadores registran sistemáticamente la población misional y sus rangos tributarios desde 1783. La recaudación, por lo tanto, sigue estos registros con algunas dificultades. La categorización se relaciona casi directamente con el monto de la tasa. Las razones para clasificar a los indios reducidos

12 AGN-Interior, 28:3. Crespo y Llanos, Carta al gobernador... 
en las misiones como "originarios, forasteros o yanaconas" varían de lugar en lugar y de tiempo en tiempo.

\section{NÚMERO DE PERSONAS CLASIFICADAS EN CATEGORÍAS TRIBUTARIAS EN APOLOBAMBA ${ }^{13}$}

Claves: [O] Originarios; [OFCT] originarios y forasteros con tierras; [F] forasteros; [Y] yanaconas; [OFTM] originarios y forasteros con tasa mayor; [oftm] originarios y forasteros con tasa menor; [OCT] originarios con tierras; [FCT] forasteros con tierras.

\begin{tabular}{|c|c|c|c|c|c|c|c|}
\hline Misión & $\begin{array}{c}\text { Originarios } \\
\text { en } 1788\end{array}$ & $\begin{array}{c}\text { OFCT } \\
\text { en } 1788\end{array}$ & $\begin{array}{c}\text { Yanaconas } \\
\text { en } 1788\end{array}$ & $\begin{array}{l}\text { OFTM } \\
\text { en } 1793\end{array}$ & $\begin{array}{c}\text { OFTm } \\
\text { en } 1793\end{array}$ & $\begin{array}{c}\text { OCT } \\
\text { en } 1803\end{array}$ & $\begin{array}{c}F C T \\
\text { en } 1803 \\
\end{array}$ \\
\hline Apolo & 1268 & 1173 & & 34 & 1229 & & \\
\hline Atén & 726 & 841 & & 35 & 1253 & & \\
\hline Isiamas & 1089 & 1015 & & & & 908 & \\
\hline Pata & 89 & 111 & & & & 104 & \\
\hline Sagunt & 211 & & 157 & & & 138 & \\
\hline Santa Cruz & 238 & & 276 & & & 8 & 344 \\
\hline Tumupasa & 416 & 523 & & & & 528 & \\
\hline Uchupiamonas & 87 & & 76 & & & 84 & \\
\hline TOTAL & 4124 & 3663 & 509 & 69 & 2482 & 1770 & 344 \\
\hline
\end{tabular}

Este cuadro nos lleva a las siguientes precisiones: 1) La población sometida a tributo pasa de 4.124 en 1788 , a 4.172 en 1793 y a 4.665 en 1803, un aumento del $13 \%$ en quince años. 2) Mientras en el registro de 1788 todos son originarios, en 1793 se dividen en 3.663 "originarios y forasteros con tierras" y 509 yanaconas y en 1803 se dividen en 69 "originarios y forasteros de tasa mayor", 2.482 "originarios y forasteros con tasa menor", 1.770 "originarios con tierras" y 344 "forasteros con tierras". 3) Esta evolución no es general sino particular de cada reducción: a) En Apolo y Atén los originarios de 1788 se reagrupan como originarios y forasteros con tierras en 1793 y en 1803 se desdoblan en originarios de distinta tasa: muy pocos pagan la "mayor" y la gran mayoría paga "la menor". b) En Sagunt, Santa Cruz y Uchupiamonas los originarios de 1788 son convertidos en yanaconas en 1793; en 1803 los de Sagunt y Uchupiamonas vuelven a revistar como originarios con tierras, mientras los de Santa Cruz aparecen como forasteros con tierras salvo un puñado que recupera la categoría originaria. c) En Isiamas, Pata y Tumupasa todos conservan la cate-

13 AGN-Sala XIII. Revisita de Indios del Partido de Caupolicán (1783:AGN, XIII-17-7-1; 1788: AGN-XIII-17-7-1; 1793: AGN-XIII-17-7-4 y 1803: AGN-XIII-17-9-4). 
goría originaria. 4) Una de las cuestiones más interesantes es la "yanaconización" de los originarios de Sagunt, Santa Cruz y Uchupiamonas en 1793. La medida es evidentemente excepcional porque funciona sólo en esos pueblos y no se repite en 1803, cuando los designan "forasteros". Pueden considerarse los siguientes factores: a) La yanaconización equivale a una rebaja del tributo que favorece a los nativos de esos pueblos habida cuenta de que los yanaconas pagan tres pesos anuales, mientras los forasteros pagan cinco y los originarios según una tasa variable que incluye la evaluación de sus recursos ordinarios. En 1803 se decide aumentarles la tasa y por eso se los pasa como "forasteros". b) Pero también puede suponerse que su adscripción como yanaconas permite someterlos al alquiler de fuerza de trabajo en haciendas españolas vecinas. Esta hipótesis tendría alguna probabilidad en Sagunt y Santa Cruz, pero sería más extraña para Uchupiamonas. De todos modos, sabemos que en 1793, Pelechuco tiene 1.364 yanaconas y Suchi 533; esta masa de casi 2.000 yanaconas parece una fuerza de trabajo suficiente para la capacidad productiva de ambas localidades, haciendo innecesario traer trabajadores de Sagunt y Santa Cruz. c) Es posible que su ingreso de 1803 a la categoría de "forasteros" se explique por el tráfico de coca, al que se incorporan progresivamente grandes masas de pequeños traficantes indígenas en las últimas décadas del dominio colonial. La adscripción territorial en esos pueblos (lo que supone, teóricamente, su definición como yanaconas) se ha tornado imposible: todos procuran migrar permanentemente.

TASAS DE TRIBUTACIÓN, APOLOBAMBA

\begin{tabular}{llll} 
Año & Misión & Reales por año & Especies \\
\hline \multirow{2}{*}{1780} & Apolo & 12 & \\
& Atén & 16 & \\
& Pata & 24 (solteros: 20) & \\
1785 & Pata & 24 & Coca \\
& Las restantes & 32 & Coca y cacao \\
1793 & Isiamas & 48 & 4 libras de cacao \\
& Pata & 24 & Tres cuartos de cesto de coca \\
& Sagunt & 24 & Tres cuartos de cesto de coca \\
& Santa Cruz & 48 & Medio cesto coca \\
& Tumupasa & 48 & 4 libras de cacao
\end{tabular}


La tasa de tributo, que siempre se paga en especies que la Real Hacienda vende en el mercado, aumenta con el número de tributarios. Cuando en 1785 se aumentan las tasas, los franciscanos se oponen firmemente sosteniendo que los indios no pueden pagarlas. Cuando el procurador general fray Bernardino Bustios pide a la Real Hacienda que exima del tributo a los habitantes de las tres misiones del norte, los oficiales reales rechazan el pedido arguyendo la riqueza productiva de la región.

El proceso de progresivo control colonial sobre el pedemonte supone, por un lado, una ampliación correspondiente de las jurisdicciones civiles y eclesiásticas, en principio indiferentes ante las precarias y a veces disparatadas empresas de conquista del siglo XVI. Pero en el XVIII la jurisdicción gubernamental se torna efectiva, particularmente una vez solucionados los límites con el Cusco. La libertad que gozaron los capitanes de huestes y los primeros misioneros, muchos de ellos mártires, se restringe poco a poco por el creciente interés del Estado y de los mercaderes que comienzan a conocer, por sí o por mentas, la riqueza productiva de Apolobamba y la posibilidad de vender esa producción en los mercados coloniales. Mercaderes y gobiernos trazan una perdurable alianza en este siglo, sobre la base de una ideología liberal que contrapone a los principios escolásticos de la Iglesia sus propias concepciones del trabajo, de la producción, del ahorro, de la renta y del beneficio. Estas críticas y proyectos son acompañados por una serie de episodios de neto corte político que ilustran el conflicto entre el Estado y las órdenes, los límites y la naturaleza de ese conflicto. En algunos casos, están en juego decisivas cuestiones estructurales (como la transferencia de las misiones de Apolobamba a la Compañía de Jesús); en otros, simples cuestiones de competencia eclesiástica. Los tiempos de la confianza gubernamental en franciscanos, dominicos y jesuitas han terminado. Estas apreciaciones, cada vez menos embozadas, exhiben la fundamental desconfianza de las autoridades en la progresiva autonomía que las misiones regulares han alcanzado. El ejemplo jesuita constituye el paradigma de esta evolución y ya se sabe cuál fue la "solución final" al problema.

\section{La culpa de los agustinos}

Aunque la evangelización de las selvas de Apolobamba fue encomendada por las autoridades virreinales a la Orden Franciscana, ya en 1618 los primeros frailes agustinos navegan el río Mapiri para fundar un pueblo de 
aborígenes de lengua leca en esa región, a diez o doce leguas de Apolo y a un día de navegación en balsa de Atén. Pero la cuestión es que casi de inmediato, 55 de estos nativos son trasladados al santuario de Nuestra Señora de Copacabana, sobre el lago Titicaca, al noroeste de La Paz, administrado por los agustinos. Si este santuario era el centro orgánico de la orden, es posible que ese traslado demostrara la función subsidiaria de la misión como simple proveedora de fuerza de trabajo. Por otro lado, las misiones agustinas en Apolobamba funcionan en tres pueblos de españoles donde habitan aymaras de tierras altas: Consata, Chiñijo y Ucumani. Los dos primeros, separados entre sí unas 30 leguas, actúan precisamente como cabeceras de sendas rutas que bajan a Mapiri.

Los agustinos se rigen, para elegir a sus autoridades, por el régimen de la "alternativa": por turno ocupan los puestos criollos y españoles. En uno de estos capítulos le toca el turno del provincialato, en función de esa alternativa, a "la nación europea". Pero el único europeo a mano es un fraile apellidado Puinea que es elegido provincial pese a haber sido acusado de apostasía y con excomunión mayor. Cuando Puinea demuestra que ocupar cargos importantes no borra automáticamente los pecados habituales, es removido y su elección ser anula. El primer resultado de este tropiezo es que la orden se queda sin alternativa. En 1762 llega a Bogotá el comisario franciscano acompañado por un lego europeo con licencia del general para "ser del coro". El arzobispo lo ordena sacerdote y en 1764 actúa ya como definidor; pocos años después asciende a provincial. Esta carrera veloz sólo se explica por su origen nacional.

Pero otra vez se encuentran indicios del rol secundario de las misiones: hacia 1763 o 1764, los españoles y mestizos de Consata y Chiñijo se quejan a Juan de Pestaña, presidente de la Audiencia y vicepatrón de este distrito, del prolongado abandono que los agustinos muestran por sus indios. Quejas semejantes presentan en 1766 los lecos reducidos en Mapiri. ${ }^{14}$ El capítulo catedralicio de La Paz comprueba "las continuas discordias que tenían entre sí los dos religiosos que las administraban, sobre cual de ellos era el legítimo superior". Por ese motivo, propone la remoción de Cuevas y el rey se apresura a encargarle a Campos, por Real Cédula del 16 de septiembre de 1767, el castigo de Cuevas y Rivera por los excesos cometidos. Frente a esta situación crítica, Gregorio Francisco Cédula...

14 ACLP, legajo 25. Campos, Gregorio Francisco de, Autos que en cumplimiento de Real 
de Campos, obispo de La Paz, actúa con celeridad: nombra dos curas seglares como capellanes en Chiñijo y Consata y le pide al prior del convento agustino de $\mathrm{La} \mathrm{Paz}$ que designe otro misionero. Pero este mismo prior debe reconocer que en sus claustros ya nadie exhibe un sincero espíritu misional. Incluso el provincial de la orden responde con enfado y displicencia cuando el obispado le reclama frailes. La crítica de Campos se torna mordaz contra la orden renuente: "del trabajo de convertir infieles e instruirlos en los dogmas católicos no se reportan utilidades temporales; si éstas se adquirieran por tales medios, yo aseguro que los agustinianos no hubieran dejado piedra por mover a fin de ser mantenidos en la posesión de sus mayores".

Ante esta situación de virtual renuncia de los agustinos, y pese a la tirria que muchos funcionarios sienten por los franciscanos, Campos (sabiendo que el propio rey se había opuesto inicialmente a esto) le pide a visitador general seráfico que le facilite un fraile. El primer enviado enferma de paludismo; el segundo es Lorenzo de la Parra, un veterano de las selvas de Apolobamba, que logra que muchos lecos regresen a Mapiri para reconstruir la iglesia (aunque muchos se quedan trabajando en el mineral de Tipuani). Entonces Campos cree oportuno elogiar la labor franciscana en la reorganización de ese pueblo y los hechos legitiman el cambio de rumbo del obispo porque en 1772, los vecinos de Consata queman la iglesia, roban todos los ornamentos y vasos sagrados y se refugian en la montaña. Lo mismo hacen los de Mapiri: de 150 personas que quedaban en la aldea, se marchan 120. ¿Hay, acaso, una decadencia del espíritu misional o es que la ambición y los enfrentamientos entre los miembros de la orden generan un estado de ansiedad y progresiva violencia entre los neófitos? En un largo informe al rey de 1776, Campos dice que la única misión agustiniana que queda es Mapiri, atribuyendo esta decadencia al hecho de que "los religiosos de estos tiempos, por carecer de aquel espíritu que deben tener los verdaderos misioneros, dejaron perder lo mucho que los antiguos trabajaron en la conversión de aquellos neófitos".

Los únicos frailes agustinos son Julián de Cuevas y Manuel de Rivera, enredados en "constantes disturbios, excomulgándose mutuamente". Ambos andan vagantes en los pueblos y están mucho tiempo ausentes de Mapiri, yendo y viniendo por Ayata, Aucapata, Ananea y Yani atraídos por los yacimientos de oro. Pero cuando Mapiri festeja a sus santos patrones, no olvidan acudir para exigir su parte del producto agrícola. 
Cuando el visitador reformador de la Orden de San Agustín en el Perú, fray Juan de la Raya, se refiere a las misiones del Mapiri enfatiza que los agustinos fomentaron la reducción de indios en las orillas del Tipuani y en los cuatro pueblos de Consata, Ucumani, Chiñijo y Mapiri. Pero la tarea que trae asignada sólo se refiere a las misiones de un modo indirecto: debe construir un Colegio de Misioneros en Copacabana. El objetivo es claro: los agustinos quieren afianzarse en un sitio que ya por entonces es uno de los grandes centros de peregrinación en los Andes. Los ingresos que depara Copacabana los estimulan mucho más que los peligrosos descensos a las selvas tropicales. Para estudiar la posibilidad de conseguir financiamiento, de la Raya le pide en julio de 1776 ayuda al prior del Santuario, fray Policarpo Brenes. No hay dinero suficiente por ahora, y los novicios deben acomodarse en las pocas instalaciones disponibles en el santuario. ${ }^{15}$

Conciente del deber misionero de la Orden, De la Raya comisiona a los frailes Manuel Maso, conventual de La Paz residente en Copacabana y Lázaro de Agramont para marchar a las misiones. Por enfermedad del primero, Agramont debe encabezar en 1777 una expedición que lleva doscientos pesos obtenidos de las rentas de Copacabana. El visitador explica que las misiones agustinas reúnen 1.500 habitantes en los cuatro pueblos, pero no puede precisar el número de habitantes en Consata y Chiñijo porque estos pueblos han sido secularizados sin permitirse desde entonces que entren los impugnados agustinos. Además, antes de la entrada de Agramont, los chunchos de Reyes (hasta 1767 al cargo de los jesuitas) habían asaltado a los lecos matando a unos y llevándose muchos prisioneros. Hay muchos lecos fugados de los pueblos, "vagantes y separados en montones en lo interior de la montaña". Sólo de Mapiri se han marchado mientras tanto casi 500. En diciembre de 1778, Agramont ha logrado reunir 150 lecos en Mapiri (sin contar los niños), exaltando la rapidez con que aprenden la fe católica. Pero necesita dinero para regalarles ropa, cotones de bayeta y hachas, cuchillos y machetes para sus labores y chalonas para su alimento; el clima húmedo y caluroso impide la conservación de la comida; termina pidiendo un socorro adicional de 200 pesos. Cuando el 20 de noviembre de 1777 el rey le ordena a De la Raya que informe sobre las misiones indicando nombres de los pueblos y número de habitantes, el

15 Archivo General de Indias (AGI). Audiencia de Charcas, 122-2-11. Raya, fray Juan de la, Visita del prior del santuario con usurpación de ellos y de la jurisdicción parroquial. 
visitador elude su responsabilidad, retrasando su respuesta hasta febrero de 1779. Se exculpa diciendo que al llegar a Lima en 1773, encontró un grave desorden en las rentas conventuales, atribuyéndolas más a negligencia que a corrupción. No estaban claros los balances de censos y rentas y en muchos casos debió separar el gravamen logrado de la aplicación del rédito. Las reglas de la orden previenen que prelados y depositarios hagan en conjunto la distribución de fondos, pero en la práctica sólo los primeros los han estado administrando. Para peor, hubo problemas de jurisdicción con el maestro provincial fray Ignacio de la Concha, que llegó a pedirle a De la Raya las instrucciones reservadas que le había dado el rey. El conflicto sigue en julio de 1774 cuando se reúne el Capítulo Provincial; y en 1776 mientras De la Raya todavía trabaja con las rentas conventuales, comprobando el exceso de frailes y el deterioro que los terremotos han producido en los edificios.

Montaño $^{16}$ asegura que Mapiri fue abandonada por los agustinos cuando los mosetenes asesinaron a fray Lázaro Agramont en el río Beni. Sin embargo, el abandono se produce cuando Agramont se retira y no es reemplazado; es cierto que luego regresa y la reorganiza, pero no consta que haya sido asesinado por los mosetenes. En esos meses, Agramont regresa a Mapiri con un sacerdote recién ordenado que conoce la lengua leca. Campos reconoce que Agramont es un religioso de suave trato y robusto para tolerar, pese a su edad avanzada, "las calamidades de Mapiri”. Cuando finalmente se lo reemplaza, se retira a Apolobamba para visitar a sus amigos franciscanos. Campos pide también que se secularicen Consata y Chiñijo, dependientes, como vimos, de Quiabaya. Además, sostiene que las Cajas Reales deben contribuir anualmente a las esas cuatro misiones ya que "jamás han tenido un maravedí seguro, se han mantenido siempre del producto de las sementeras que hacen los neófitos habilitados por los religiosos (..) y también de las limosnas que algunos devotos les hacen". ${ }^{17}$ Para peor, los tres pueblos de Chiñijo, Consata y Ucumani, antiguas poblaciones aymaras que funcionan como estratégico frente pionero para negociar con el altiplano y los valles coqueros, se suman a la insurrección tupamarista de 1780-1783. El propio Segurola, inspirador visible de los reproches sistemáticos contra las órdenes, exalta

16 Montaño Aragón, Mario, Guía Etnográfica-Lingüística de Bolivia. La Paz, 1989. Cédula...

17 ACLP, legajo 25. Campos, Gregorio Francisco de, Autos que en cumplimiento de Real 
el papel de Agramont como intercesor entre los españoles perseguidos por la rebelión y los lecos, que aceptaron generosamente resguardarlos en Mapiri, facilitándoles después un exilio más seguro en Reyes y Sagunt. Con la derrota de la gran insurrección, las autoridades recuperan los accesos a las misiones, impulsando otra vez al movimiento evangelizador. Se fundan nuevas reducciones y se revitalizan reductos jesuitas abandonados desde la Expulsión.

Una carta anónima, firmada en Tipuani y remitida al virrey de Buenos Aires por el correo general del Perú en septiembre de $1784^{18}$ insiste sobre la falta de agustinos en las misiones. Como solución se propone instituir el Santuario de Copacabana, controlado por esa orden, como "recoleta de misioneros" sujetos al obispado. Se espera que con esa función, el Santuario atraiga más vocaciones; la propuesta esconde una crítica: de ese modo, los 15.000 pesos que cada cuatro años se llevan a Lima los priores y provinciales de esa orden, deberán servir, forzosamente, para que renazca la empresa agustina. "Es común voz y fama — agrega — que si los miles que han apercibido los priores y padres provinciales se hubieran empleado en beneficio del santuario, serían las paredes de plata maciza”. La persistente ausencia de misioneros se liga con la codicia y la corrupción. En vez de emplear el dinero en favor de los enfermos internados en los hospitales de San Juan de Dios, los priores agustinos lo usan para comprarles regalos a sus comisarios con la esperanza de conseguir ascensos. Véase el caso del reformador fray José Colomina, que regresa a España "cargado de plata y sus conventos pobres porque un solo individuo sea rico a costa del atraso de los pobres y de la pérdida de su desdichada alma". En vista de estos hechos, la Visita de De la Raya no deja satisfechas a las autoridades. En noviembre de 1785, Carlos III le ordena al obispo de La Paz y al intendente Segurola que informen sobre la situación de Mapiri. Siguiendo la costumbre, ambos se toman todo su tiempo para responder: Campos lo hace en agosto de 1787 y Segurola en febrero de $1788 .{ }^{19}$ Campos, a quien todos reconocen como pro-franciscano (no es paradójico que sea un franciscano, fray Lorenzo de la Parra, quien reduce a los lecos fugados de Mapiri), reconoce algunos errores en el informe del

18 AGN-Interior, 28:3. Bustios, fray Bernardino, Informe del misionero apostólico de las Misiones de la Purísima Concepción de Apolobamba, 1784.

19 AGI-Audiencia de Charcas, 121-2-11. Campos, Gregorio Francisco de, Informe del obispo de La Paz al rey, 6 de agosto de 1787 y Segurola, Sebastián de, Informe del gobernador-intendente de La Paz, 1. ${ }^{\circ}$ de febrero de 1788. 
visitador agustino, que deben atribuirse a su falta de información real: por ejemplo, sólo Mapiri es pueblo de lecos, mientras los tres restantes son fundaciones antiguas. Chiñijo y Consata son anexos de Quiabaya y Ucumani anexo de Ayata, ambos en Larecaja, donde residen muchos españoles y mestizos atraídos por el cultivo de coca. En esos pueblos los agustinos trabajaron como doctrineros y tenientes de los curas seglares de Quiabaya y Ayata, no como misioneros. Para salvar lo que considera errores, Campos pide que Mapiri se agregue al sistema misional franciscano de Apolobamba.

En segunda instancia, Campos examina otorgar fondos de Vacantes o Expolios a los misioneros. Le comunica al rey que en la respuesta del visitador provincial fray Manuel Belaochaga, podrá reconocer la "total indolencia, omisión y descuidos de los frailes [agustinos]". Pero Belaochaga protesta en voz alta en enero de 1789: la mala conducta de los misioneros Cuevas y Rivera no debe oscurecer la dignidad de toda una Orden que tanto ha hecho entre los infieles. El mismo se pone como ejemplo: ha debido viajar de Mapiri a Sorata para comprar sal, bayetas y herramientas porque en las misiones, por falta de fondos gubernamentales, se han quedado sin herreros; pide que los pueblos se restituyan a los agustinos y que se otorguen fondos seguros para sus frailes. Todos consideran que Agramont es un misionero insigne y las autoridades confían en él, pero se sabe que necesita un compañero que cuide el pueblo mientras busca a los fugados. Campos exhorta a poner tres frailes en Mapiri, dos por lo menos, porque el empeñoso Agramont siempre ha estado solo. ¿Qué, ocurriría si se enfermara o debiera hacer alguna diligencia?

Segurola explica que tras la ausencia de Agramont la gente de Mapiri se redujo notablemente, huyendo muchos a las montañas a causa de la ineptitud y repetidas ausencias de su sucesor, fray Blas de Cárdenas, y la reyerta entre Agramont y el nuevo prior de los agustinos, fray Juan Santibáñez, que vino a las misiones en reemplazo de fray José Montesinos, quien poco después de su designación cae paralítico en Sorata y muere tras su regreso a La Paz. Si bien es cierto que Cárdenas estuvo enfermo de paludismo, Segurola desconfía de sus condiciones de misionero: en dos cartas de febrero de 1789 , una dirigida al rey y otra al virrey de Buenos Aires, denuncia que Cárdenas ignora la lengua leca; antes lo ha denunciado al obispo que no contestó por "estar muy enfermo". Los funcionarios denuncian que Santibáñez fue nombrado en abierta trasgresión de las leyes de Indias, algo que acepta hasta el conciliador obispo 
Campos. La juventud y poca experiencia de Santibáñez le restaban "la prudencia, sagacidad y política" que exigía el gobierno de los neófitos. Pronto el prior puso de manifiesto "su violencia y genio orgulloso". Segurola está convencido de que Santibáñez no vaciló en acusar a Agramont de lograr "ingentes utilidades con comercios y granjerías" y que por ello, aún habiendo estado Agramont mucho tiempo en las misiones, no había llevado dinero a sus superiores. La crítica de Santibáñez a un hombre de tal prestigio como Agramont no fue bien recibida en la diócesis: el acusador es removido y se le pide a Agramont que regrese con el poco dinero recibido.

\section{El convento de Copacabana}

La crítica de Segurola contra el prior Santibáñez no tarda en extenderse al propio núcleo agustino: el convento de Nuestra Señóra de Copacabana. Carece de las formalidades que el derecho exige para su erección, ya que fue en origen una iglesia secular luego subrrogada por un fraile agustino. En esa ocasión, los agustinos reunieron una junta y armaron un convento, adjudicándose el Santuario local a la Virgen, "celebrada con universales (y) crecidas limosnas", reservándose sus priores y las rentas de las visitas diocesanas. ¿Necesitan los agustinos, realmente, fondos especiales para sus misiones? Segurola piensa que el convento de Copacabana, objeto de vasta veneración popular y visitado por miles de peregrinos todo el año, tiene fondos suficientes no sólo para mantener dos religiosos en la misión sino para todos los demás. La piedad pública ha estatuido capellanías y censos en favor de los prelados locales y provinciales sin otro gasto que el alimento cotidiano, dos o tres velas por semana y tres o cuatro pesos. Pese a ello, los agustinos sólo remitieron a las misiones treinta pesos (por no poderlos recaudar en Ambaná). El párroco de Copacabana, encolerizado por los privilegios que a su juicio favorecen tan injustamente a los agustinos en desmedro del clero seglar, suscribe espontáneamente los argumentos de Segurola. Confecciona una lista mensual de los ingresos por alferados y donaciones piadosas del curato-santuario, de donde, al menos teóricamente, debe tomar los fondos necesarios para abastecer su misión de Mapiri. Los ingresos del priorato agustino de Copacabana eran bastante jugosos: 
COMERCIO Y TRIBUTO EN APOLOBAMBA

INGRESOS DEL PRIORATO AGUSTINO DE COPACABANA

\begin{tabular}{|c|c|c|c|}
\hline Mes & Festividad religiosa & $\begin{array}{l}\text { Ingresos del } \\
\text { prior }\end{array}$ & $\begin{array}{c}\text { Ingresos del } \\
\text { párroco }\end{array}$ \\
\hline \multirow[t]{2}{*}{ Febrero } & Purificación y San Blas & 200 & 24 \\
\hline & Octava de Nuestra Señora & 24 & 2 \\
\hline \multirow[t]{3}{*}{ Marzo } & Señor San José & & \\
\hline & Dolores de Nuestra Señora & & \\
\hline & Semana Santa & 200 & \\
\hline \multirow[t]{2}{*}{ Junio } & Corpus Christi & 24 & \\
\hline & Octava de Hábeas & 24 & 2 \\
\hline \multirow[t]{3}{*}{ Agosto } & San Agustín (alferado 1) & 10 & 2 \\
\hline & San Agustín (alferado 2) & 12 & \\
\hline & San Roque & 22 & 2 \\
\hline \multirow[t]{2}{*}{ Septiembre } & San Nicolás & 12 & \\
\hline & Exaltación & 24 & \\
\hline \multirow[t]{2}{*}{ Octubre } & Rosario & 24 & \\
\hline & Octava del Rosario & 12 & \\
\hline \multicolumn{4}{|l|}{ Noviembre } \\
\hline \multirow[t]{2}{*}{ Diciembre } & Concepción & 100 & \\
\hline & Fiesta privada de San Antonio & & \\
\hline
\end{tabular}

TOTAL

712

32

Además de quedarse con el $95.7 \%$ de los ingresos, el prior se reserva las contribuciones por cabos de año, honras y misas de vigilia cantadas en la iglesia, ofrendas a los difuntos y todo cuanto ponen en la iglesia los dolientes. También los entierros mayores y menores y los novenarios de misas. El párroco sólo preside las procesiones en el cementerio local y no recibe nada del producto de la estancia agustina de Guacuyo. Como consuelo, el convento le proporciona seis velas semanales, un real de pan diario y veinte reales por mes para cantar las misas de los novenantes, rezar el coro y tocar las campanas, sin "gozar ninguna distinción por su carácter ni ministerio de párroco, hecho el ultraje y vilipendio entre todos". En resumen, todos los actos litúrgicos son ordenados y supervisados por el prior agustino que se apodera de casi todos los ingresos, dejándole migajas al 
párroco del santuario. Este conflicto estimula al clero seglar y a las autoridades diocesanas a vigilar de cerca a los agustinos, sobre todo, naturalmente, en sus reiteradas actitudes de pedir dinero al gobierno. En 1789 el Consejo de Indias recibe un informe del gobernador Segurola del año anterior sobre el abandono agustino, donde denuncia que las cuatro misiones están en su "mayor abandono" y que desde 1784 las autoridades procuran superar la situación..$^{20}$ Demostrando por qué sus preferencias por la Orden de san Francisco, Campos señala que los seráficos de Apolobamba nunca han faltado de sus misiones y si alguno muere o es enviado a otra parte se lo reemplaza de inmediato; que las misiones no han prosperado más porque no tienen rentas para mantenerse y hacer los acostumbrados regalos a los indios. Con unas pocas plantaciones de arroz y maní no se podría financiar todo el sistema misional.

\section{Finale}

Mientras las misiones jesuitas quedan desbaratadas rápidamente mediante un golpe oficial, las franciscanas y agustinas sobreviven en plena decadencia. Reaparecen durante el XIX pero en el marco institucional más rígido de las repúblicas militares. Las críticas ilustradas no fueron en vano: la exportación de bienes locales hacia el mercado de La Paz se hace regular y el tributo se impone finalmente permitiendo que durante las tres últimas décadas del período colonial, la Corona extraiga de estas regiones una parte importante del valor de su producción. Este sistema tributario actúa incluso como modelo para las futuras imposiciones estatales de la etapa republicana. El peculiar orden social franciscano, que evoca el más perfeccionado de la Compañía de Jesús, desaparece por completo y su influencia histórica decrece en los siglos siguientes.

Recibido el 2 de febrero de 2005 Aceptado el 15 de mayo de 2005

20 AGI-Audiencia de Charcas, 121-2-11. Segurola, Informe del gobernador-intendente. 
COMERCIO Y TRIBUTO EN APOLOBAMBA

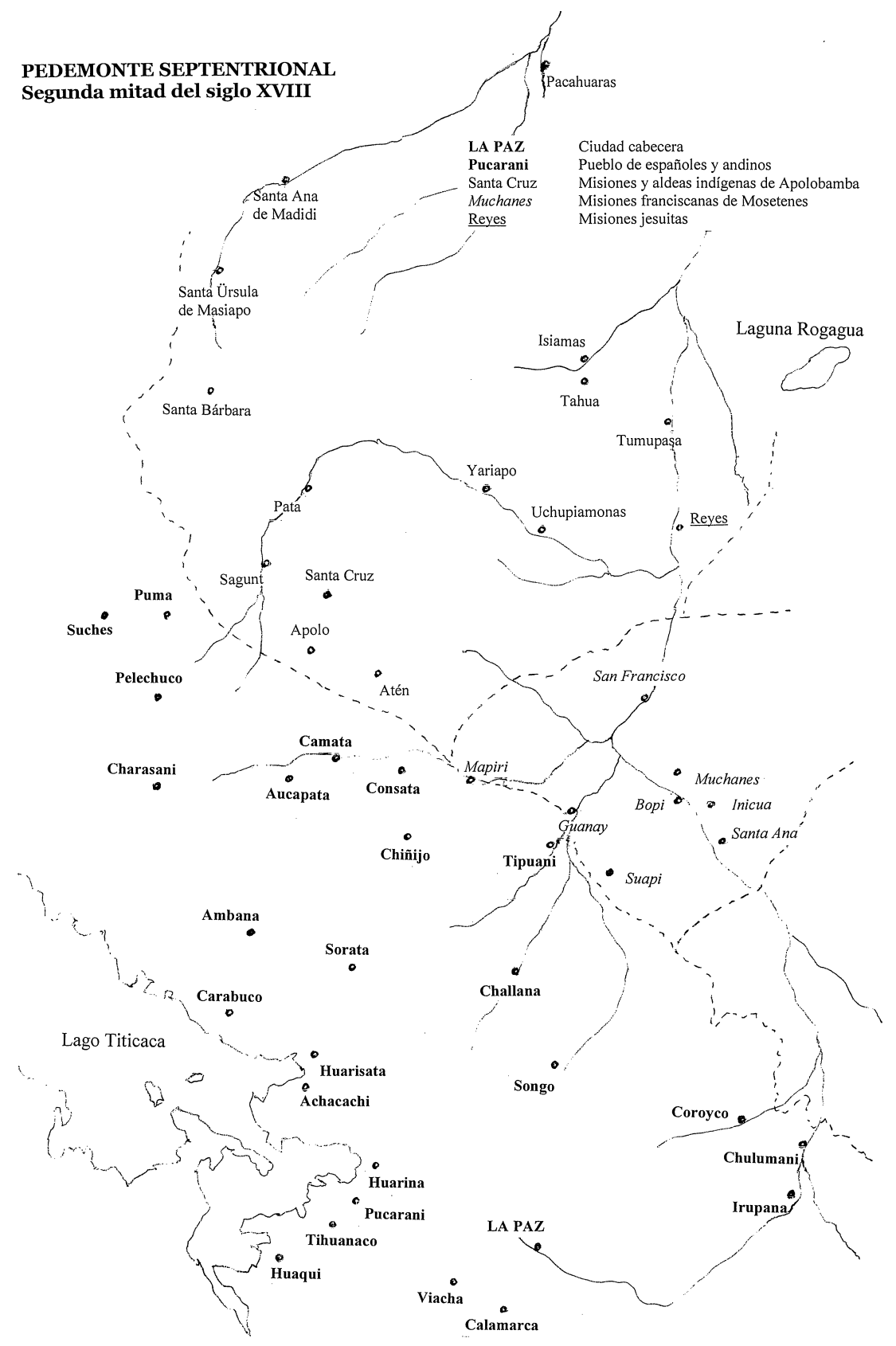

AEA, 62, 2, julio-diciembre, 2005, 137-161. ISSN: 0210-5810 